\title{
Epidermal growth factor receptor-mediated innate immune responses and their roles in
} airway diseases

\author{
P-R. Burgel* and J.A. Nadel ${ }^{\#}$
}

ABSTRACT: Inhaled air is contaminated with pathogens and particulates that may deposit in the airways and damage the host. In response to these invaders, the airway epithelium has developed innate immune responses that provide a defence against the invaders and protect the airway structure and function. Thus, the epithelium of conducting airways becomes the "battleground" between the invaders and the host.

Recent evidence suggests that airway epithelial surface signalling through the epidermal growth factor receptor (EGFR) is a convergent pathway producing innate immune responses to a variety of infectious and noninfectious noxious stimuli. In the present review, the EGFR signalling pathways leading to airway mucin production, neutrophil recruitment (via interleukin-8 production) and airway epithelial repair were examined.

The importance of these findings in human airway diseases was also investigated. The current authors suggest that the exaggerated innate immune responses found in chronic inflammatory airway diseases (e.g. chronic obstructive pulmonary disease, cystic fibrosis and severe asthma) contribute to the pathogenesis or the aggravation of these diseases. Potential therapies include inhibition of the various elements of the described epidermal growth factor receptor cascade. In considering each therapeutic intervention, the potential benefits must be considered in relation to potential deleterious effects.

KEYWORDS: Asthma, chronic obstructive pulmonary disease, cystic fibrosis, interleukin-8, mucins, neutrophils

W ater-based animals utilise gills for the exchange of oxygen and carbon dioxide. As animals migrated to land during evolution, the expanded respiratory exchange apparatus was moved deep within the thoracic cavity and the lungs (the organs for gas exchange) required "air tubes" (the conducting airways) to communicate with atmospheric air. Inhaled air is contaminated with potential invaders, e.g. bacteria, viruses and other particulate irritants, such as allergens and cigarette smoke. Thus, the airway epithelium has become the "battleground" between invaders and host. An early system for immediate responses to the invaders was developed as a first line of defence; these local defences have been called "innate immune responses". They are "innate" because they do not require prior exposure to the invading microbe and they have the capability (i.e. receptors) to intercept microbial signals constitutively. They are "immune" in that they protect against infectious diseases.

Innate immunity in the lungs is an area of research that is evolving rapidly. This includes the mechanisms utilised by the airway epithelial cells to detect individual microbial and other products and the effector molecules produced for defence by the epithelium [1,2]. During the past decade, receptors called pattern-recognition receptors (PRRs) have been identified, which recognise the presence of inhaled pathogens. The airway epithelium expresses PRRs, such as Tolllike receptors (TLRs), which recognise specific pathogen motifs. The PRRs play major roles in innate immune responses because their recognition of pathogens triggers host responses that are mediated by various effectors. Among the effector molecules are antimicrobial peptides that are produced and secreted by the epithelial cells and
AFFILIATIONS

*Service de Pneumologie and UPRES EA 2511, Université Paris Descartes, Hôpital Cochin,

Assistance Publique-Hôpitaux de Paris, Paris, France.

${ }^{\#}$ Cardiovascular Research Institute and Depts of Medicine and Physiology, University of California, San Francisco, CA, USA.

CORRESPONDENCE

J.A. Nadel

Cardiovascular Research Institute Box 0130

University of California San Francisco

San Francisco

CA 94143-0130

USA

Fax: 14154768391

E-mail: jay.nadel@ucsf.edu

Received:

December 192007

Accepted after revision:

April 022008

STATEMENT OF INTEREST

None declared.

European Respiratory Journal

Print ISSN 0903-1936

Online ISSN 1399-3003 
that display microbicidal activity or inhibit growth of inhaled microorganisms [3, 4]. Mucins secreted by airway cells are recognised to be important in the adhesion to $[5,6]$ and clearance of microbes by mucociliary transport and cough [7, 8]. Extravasation of leukocytes in the airways and their phagocytosis of inhaled particulates are important in the normal eradication of the invaders [2]. Damage to epithelial tissue is also repaired by epithelial innate defence mechanisms. Normally, local responses are adequate to destroy the pathogens without obvious inflammation, and normal structure and function are maintained without symptoms. In contrast, exaggerated or inappropriate innate immune responses have been hypothesised to result in abnormal structural and functional outcomes and, thus, in disease [2].

In the present review, the focus is on the epidermal growth factor receptor (EGFR) signalling pathway, which produces specific protective responses by the epithelium, with special emphasis placed on mucin production and secretion (for mucociliary clearance of invading organisms), neutrophil recruitment (for bacterial killing) and epithelial wound healing (for repair of injured tissue). EGFR is the prototypical member of the ErbB family, which comprises of four receptors: EGFR/ ErbB1/human epidermal growth factor receptor (HER)1, ErbB2/Neu/HER2, ErbB3/HER3 and ErbB4/HER4 [9]. These are transmembrane receptors containing a ligand-binding site in the extracellular domain, a single membrane-spanning region and a cytoplasmic protein tyrosine kinase-containing domain. Upon activation by their cognate ligands, ErbB receptors form dimers (either homodimers or heterodimers), leading to activation of the intrinsic kinase domain, which results in phosphorylation of specific tyrosine residues in the intracellular domain. In the human airway epithelium it has been reported that EGFR, HER2 and HER3 are expressed, whereas expression of HER4 is absent or barely detectable [10, 11]. Thus, EGFR homodimers and EGFR-HER2 or EGFR-HER3 heterodimers may form when EGFRs are stimulated with their ligands. The formation of heterodimers between EGFR and other members of the ErbB family are likely to be important in determining cellular fate and responses. Since little data exists on the roles of EGFR heterodimers in innate immune responses of the airway epithelium, the present review focuses on EGFR. Emphasis is placed on potential roles of this complex signalling pathway in airway epithelial defences. Finally, relevant studies in human subjects with airway diseases are reviewed.

\section{MECHANISMS OF CELL SURFACE SIGNALLING AND EGFR ACTIVATION}

\section{Mucin production via EGFR signalling}

\section{Description of mucins and stimuli inducing mucins}

It has long been known that some chronic airway diseases (e.g. asthma, chronic obstructive pulmonary disease (COPD) and cystic fibrosis (CF)) are associated with mucous hypersecretion. Among the major components of human mucus are large-sized glycoproteins, the gel-forming mucins [12]. Understanding of mucous hypersecretion began with the cloning of these mucin genes [13-16]. During the 1990s, several studies reported that multiple stimuli upregulate mucin gene expression and protein production [17-30].

\section{Involvement of EGFR activation in mucin production}

Li et al. [31] reported that the intracellular downstream pathway for mucin production in response to Pseudomonas aeruginosa bacteria included a Src-dependent Ras-mitogen-activated protein kinase-pp90rsk pathway, but no surface receptor or surface signalling pathway was described. In 1999, TAKEYAMA et al. [32] discovered that EGFR activation results in mucin production, an effect that was prevented by selective EGFR tyrosine kinase inhibitors. EGFR is a $170-\mathrm{kDa}$ membrane glycoprotein, which is expressed in various epithelial cells, including airways. In studies of rats in vivo, it was also shown that ovalbumin-induced sensitisation of rat airways increased goblet cell production via an EGFR pathway [32]. Treatment with EGFR inhibitors also prevented interleukin (IL)-13-induced mucin production in rat airway epithelium in vivo [33]. Thereafter, a profusion of studies reported that various stimuli cause mucin production via EGFR activation in human airway epithelial cell lines, normal human bronchial epithelial cells and in animals in vivo [34].

\section{Ligands involved in EGFR activation}

EGFR ligands, including epidermal growth factor (EGF), transforming growth factor (TGF)- $\alpha$, heparin-binding (HB)EGF, amphiregulin, betacellulin and epiregulin, bind to EGFR, leading to direct activation of the receptors [35]. Many inflammatory cells produce these ligands, including eosinophils [36, 37], neutrophils [38], mast cells and macrophages [38, 39]. Thus, both activated eosinophils [37] and activated mast cells [40] have been shown to induce mucin synthesis in airway epithelial cells via the release of EGFR ligands. The roles of bone marrow-derived cells in EGFR signalling in disease deserve further investigation.

\section{Ligand-dependent EGFR activation}

Many stimuli do not activate EGFR directly. For example, ligands for G-protein-coupled receptors (GPCRs), such as endothelin-1, lysophosphatidic acid, thrombin [41] and IL-8 [42], induce epithelial EGFR activation. Airway epithelial cells produce EGFR proligands [10], synthesised as transmembrane precursors that require cleavage by metalloproteases to release the soluble mature ligands [43]. Originally, no soluble ligands were detected in the culture medium when epithelial cells were treated with GPCR activators [41, 44], suggesting that this EGFR activation does not involve EGFR-ligand binding. The activation was presumed to occur solely via intracellular mechanisms (so-called "ligand-independent" EGFR phosphorylation). Subsequently, PRENZEL et al. [45] showed that GPCR activation releases EGFR ligands into the cell culture medium, implicating ligand release from the epithelial cells in GPCR-induced EGFR activation. In that study, batimastat, a general metalloprotease inhibitor, prevented GPCR-induced EGFR ligand release, EGFR phosphorylation and subsequent cell proliferation, implicating an epithelium-derived metalloprotease in GPCR-induced EGFR signalling.

Lipopolysaccharide (LPS), a secreted product of Gram-negative bacteria, was reported to induce mucin production by unknown innate surface signalling mechanisms [30, 31]. Subsequently, KoHRI et al. [46] showed that P. aeruginosa bacterial supernatant induces mucin production in human airway epithelial (NCI-H292) cells via EGFR activation. Additionally, KOHRI et al. [47] reported that stimulation with 
human neutrophil elastase induces mucin production in cultured airway epithelial cells via EGFR activation. In the latter study, the authors showed that elastase-induced mucin production occurs via proteolytic activation of an EGFR signalling cascade involving the cleavage of TGF- $\alpha$ (a "liganddependent" process) [47]. The metalloprotease responsible for ligand cleavage was not identified.

\section{Tumour necrosis factor- $\alpha$ converting enzyme and other} metalloproteases cleave EGFR proligands

Epithelial cells contain the metalloprotease tumour necrosis factor- $\alpha$ converting enzyme (TACE), a member of the a disintegrin and metalloprotease (ADAM) family, a group of zinc-dependent transmembrane metalloproteases [48, 49]. TACE cleaves EGFR proligands, such as pro-TGF- $\alpha$, in epithelial tissues [50]. SHAO et al. [51] showed that the supernatant of $P$. aeruginosa and LPS increase mucin MUC5AC gene expression and protein production via an EGFR-dependent pathway: pre-incubation of the epithelial cells with an EGFR-neutralising antibody or with a TGF- $\alpha$-neutralising antibody prevented MUC5AC synthesis, implicating ligand (TGF- $\alpha$ )-dependent EGFR phosphorylation. Knockdown of TACE inhibited the epithelial responses to LPS, including mucin production, thus establishing TACE as an important cell surface metalloprotease involved in airway epithelial defences against microbial presence [51]. Several members of the ADAM family of metalloproteases, including ADAM10, -12, -15 and -17, have been reported to cleave EGFR proligands in response to GPCR activation [52]. LEMJABBAR et al. [53] showed that stimulation of epithelial cells with lipoteichoic acid resulted in the activation of platelet-activating factor (PAF) receptor, a GPCR, leading to ADAM10-mediated shedding of pro-HB-EGF from the epithelial cell surface and subsequent mucin production. Thus, various ADAM family members may be involved in pro-EGFR ligand shedding and mucin production, depending on various features including the stimulus and the epithelial source.

\section{Reactive oxygen species and Dual oxidase 1 activate TACE}

Airway epithelial cells produce reactive oxygen species (ROS) [54], which are known to be involved in cell signalling [55]. In airway epithelial cells, ROS scavengers prevent cigarette smoke-induced TACE activation, EGFR phosphorylation and mucin production, implicating ROS in the activation of the TACE-EGFR pathway [56]. ROS are not only present in cigarette smoke and other inhaled substances, but are also generated by nicotinamide adenine dinucleotide phosphate (NADPH) oxidase [57]. Dual oxidase (Duox)1 is expressed in airway epithelial cells and generates ROS via NADPH oxidase activity [58, 59]. Stimulation of airway epithelial cells with neutrophil elastase induced TACE activation, TGF- $\alpha$ release and mucin production, effects that were prevented by ROS scavengers, implicating ROS in TACE activation [60]. Knockdown of Duox1 expression by small interfering RNA prevented the neutrophil elastase-induced responses, implicating Duox1 in TACE activation and mucin expression. The protein kinase $C(\mathrm{PKC}) \delta / \mathrm{PKC} \theta$ inhibitor rottlerin also prevented these responses, implicating their role in Duox1 activation [61]. These results expand the epithelial surface signalling cascade that induces mucin production to include

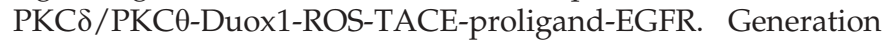
of ROS can also be derived from stimuli, such as cigarette smoke [62], and from cells recruited from the blood (e.g. neutrophils, eosinophils and macrophages) [63].

\section{Activation of EGFR signalling by binding of environmental stimuli to cognate receptors}

Inhaled "invaders" that deposit on the airway epithelium are recognised by airway epithelial cells via PRRs. Among these, TLRs are expressed in various immune cells (e.g. macrophages, dendritic cells, B-cells and specific types of T-cells) [64] and in airway epithelial cells. Thus, it has been shown that at least 10 TLRs (TLR1-10) are expressed in airway epithelial cells [65, 66]. Each TLR recognises specific ligands, resulting in cellular cascades that may produce different host responses [1]. For example, TLR2 recognises Gram-positive lipoteichoic acids and peptidoglycan, TLR3 recognises viral double-stranded RNA, TLR4 recognises Gram-negative LPS, TLR5 recognises flagellin and TLR9 recognises unmethylated bacterial DNA [1].

The airway epithelium is polarised and contains tight junctions that provide a physical barrier to particulates and large protein molecules, preventing their passive penetration through the epithelium [67]. The host response to inhaled pathogens can be initiated by extracellular microbial stimuli and does not necessitate invasion of the epithelial cells [68]. Thus, in airway epithelial cells, TLRs can be located at the apical membrane, where microbes or microbial products deposit. However, in phagocytes, some TLRs (TLR1, $-2,-4,-5$ and -6) are reported to be expressed at the cell surface, whereas other TLRs (TLR3, -7, -8 and -9) are reported to be expressed intracellularly [64]. Several investigators have studied the subcellular localisation of TLRs in airway epithelial cells. SoONG et al. [69] showed that only small amounts of TLR2 were present on the apical surface of airway epithelial cells under basal conditions, but bacterial stimulation caused TLR2 recruitment to the apical membrane of airway epithelial cells. TLR3 was not detected at the cell surface under basal conditions but was detected at the surface of cultured airway epithelial cells after stimulation with respiratory syncytial virus [70]. In each case, the recruitment of TLR2 or TLR3 at the cell membrane resulted in chemokine (e.g. IL-8) secretion. Similarly, GREENE et al. [66] reported that activation of TLR4 at the epithelial cell surface induces IL-8 secretion in CFTE29o- and 16HBE14o- cells. However, GUILLOT et al. [71] showed that TLR4 is expressed intracellularly in A549 and in BEAS-2B cells. In these cells, extracellular LPS stimulated TLR4 via unknown mechanisms. Therefore, the present authors conclude that TLR localisation is a dynamic process regulated by pathogen exposure, which may generally (but not always) lead to recruitment of TLRs at the cell membrane.

Multiple studies have reported that stimulation of airway epithelial cells by LPS induces the secretion of IL-8 via a cellular cascade involving a TLR4/myeloid differentiation primary response gene (MyD)88/nuclear factor- $\kappa B$-dependent pathway [66, 72]. NAKANAGA et al. [73] reported that LPSmediated IL-8 production is dependent on the Duox1-TACETGF- $\alpha$-EGFR signalling pathway located on the cell surface. These data suggest that, after recognition of LPS by TLR4, a signalling cascade may lead to EGFR activation. In phagocytes, after TLR4 activation, MyD88 is recruited to the Toll/IL-1 receptor domain, resulting in phosphorylation of $\mathrm{p} 47^{\text {phox }}$, a critical component of NADPH oxidase, leading to ROS 
production [74]. The current authors suggest that similar mechanisms occur in airway epithelial cells. Interestingly, MCNAMARA and BASBAUM [75] reported that a dominant negative mutant MyD88 inhibited LPS-induced mucin production in NCI-H292 cells, supporting the speculation that MyD88 may activate Duox1 and EGFR.

A second group of receptors that signal epithelial responses are GPCRs [76]. These form the largest family of cell surface receptors and mediate signals from an enormous diversity of extracellular molecules, including acetylcholine, endothelins, prostaglandins, thrombin, ATP and UTP, PAF and lysophosphatidic acid. Interestingly, GPCRs also participate in the recognition of some inhaled noxious stimuli. For example, PAF receptors contribute to the recognition of Gram-positive bacteria (e.g. Streptococcus pneumoniae and Staphylococcus aureus) $[53,77]$, and acetylcholine receptors are activated by nicotine (e.g. from cigarette smoke) [78]. Activation of PAF receptors by $S$. aureus lipoteichoic acid induces mucin production via EGFR activation in airway epithelial cells [53]. In addition to the ability of GPCRs to participate in the responses to inhaled microbes, these receptors may respond to autocrine signals provided by locally produced molecules, such as ATP/ UTP, for example as a result of a local inflammatory process. This is an area for future investigation.

Other non-TLRs and non-GPCRs are important for recognition of some pathogens by the airway epithelium. For example, $S$. aureus protein $\mathrm{A}$ is reported to interact directly with EGFR in airway epithelial cells, leading to EGFR activation [79]. Intercellular adhesion molecule (ICAM)-1, which is the major human rhinovirus receptor in phagocytes [80], is also involved in the recognition of some rhinoviruses in airway epithelial cells [81]. The relationship between ICAM-1 signalling and EGFR activation is an interesting area for future studies.

\section{Summary of the EGFR signalling pathway}

When inhaled atmospheric irritants deposit on the airway epithelium and bind to a receptor such as a TLR or GPCR, activation of the receptor leads to a series of downstream signals and multiple outcomes. Among these signalling events is EGFR activation, which may result in cell migration and proliferation, wound repair and/or the production of proteins involved in innate immune responses (e.g. upregulation of IL-8, mucins and antimicrobial peptides). The sequence of events from stimulus to EGFR activation is best described as a cascade. There are probably multiple unknown steps in this cascade. Furthermore, the future investigation of positive and negative feedback systems involving this EGFR cascade could lead to important discoveries related to epithelial cell regulation in health and disease. A diagrammatic representation depicting surface mechanisms that lead to EGFR activation in response to inhaled pathogens is presented in figure 1.

\section{IL-8 synthesis via EGFR signalling}

Neutrophils have been recognised to play important roles in chronic airway diseases such as CF [82], COPD and severe asthma. IL-8 is a chemokine that is expressed in many cell types, including airway epithelial cells [83]. IL-8 is a potent and selective chemoattractant for neutrophils in vitro [84] and in vivo [85]. IL-8 has also been shown to be an important

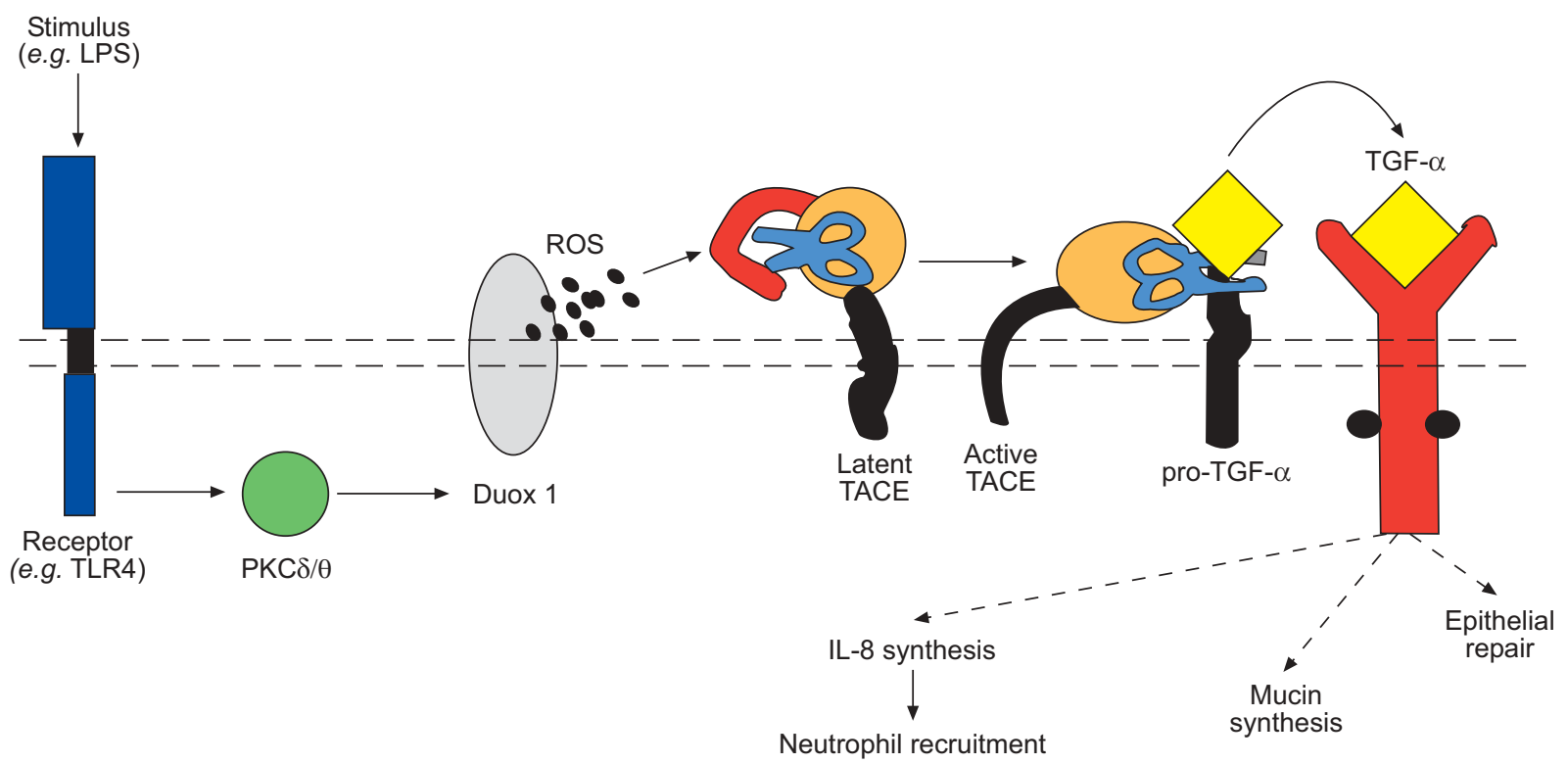

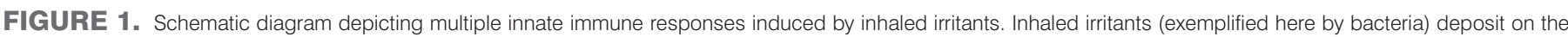

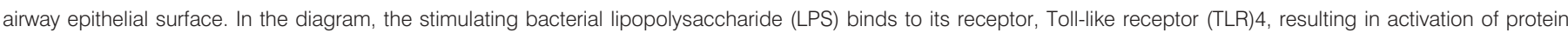

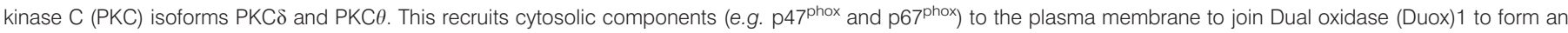

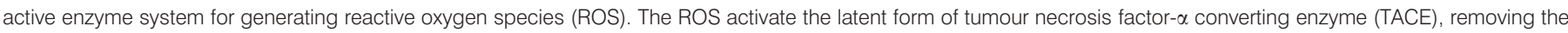

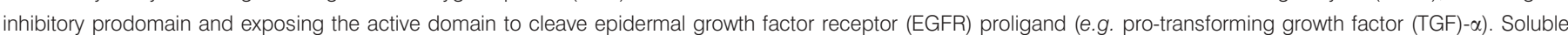

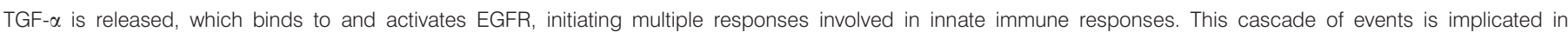

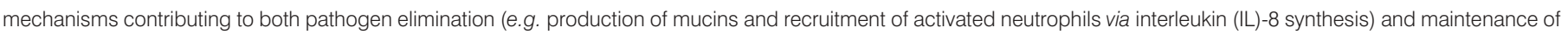
host integrity (e.g. epithelial repair). 
neutrophil chemoattractant in the sputum of patients with chronic inflammatory diseases, including $\mathrm{CF}$, bronchiectasis and chronic bronchitis [86]. IL-8 is produced by the airway epithelium in response to various stimuli, such as Pseudomonas bacteria [87], bacterial LPS [88], S. aureus [89] and ragweed antigen [90].

An important recent finding is that the synthesis and secretion of IL-8, a major neutrophil chemoattractant in airway epithelial cells, is also dependent, at least in part, on EGFR activation. SUBAUSTE and PROUd [91] first showed that treatment of airway epithelial cells with increasing concentrations of EGF or TGF- $\alpha$, two EGFR ligands, resulted in increased secretion of IL-8. Subsequently, RICHTER et al. [92] showed that cigarette smoke, which has been shown to activate EGFR resulting in mucin production [93], also induces the gene transcription and protein production of IL-8, effects that are prevented by the selective EGFR tyrosine kinase inhibitor AG1478 [92]. They also showed that the EGFR-dependent IL-8 secretion in response to cigarette smoke was the result of TGF- $\alpha$ shedding from airway epithelial cells [92]. NAKANAGA et al. [73] showed that TACE is responsible for the synthesis and release of IL-8 from airway epithelial cells in response to bacterial LPS via a Duox1-TACE-TGF- $\alpha$-EGFR signalling pathway on the surface of airway epithelial cells. Neutrophil elastase induces IL-8 production in airway epithelial cells via similar surface signalling [94].

\section{Epithelial wound repair via EGFR signalling}

Epithelia constitute an important barrier against invading microorganisms, and the epithelial innate immune mechanisms provide important pathways for repairing wounded epithelium. It has long been suspected that EGFR signalling induces accelerated wound repair [95]. Wound repair of human surface respiratory epithelium has been studied using cultured human epithelial respiratory cells in which wounds were created mechanically [96]. Investigators have shown that when EGFR is activated by its ligands (delivered exogenously), wound repair is accelerated in alveolar [97], airway [98], intestinal [99, 100], mammary gland [101] and skin epithelia [102, 103].

Damage to airway epithelial cells could cause accelerated wound repair via mechanical stimulation. Thus, after mechanical stress, endogenous nucleotides, such as ATP and UTP, are released into the extracellular space from mechanically stressed epithelium, stimulating epithelial cell proliferation [104, 105]. These nucleotides bind to specific GPCRs and to non-GPCRs. They stimulate IL-8 production in airway epithelial cells in a Pertussis toxin-sensitive manner, suggesting that GPCR activation plays a role in IL-8 production [105]. Other studies have shown that EGFR activation induces IL-8 production, and GPCR stimulation is known to cause EGFR activation [45]. Further investigation of the roles of mechanically damaged epithelium and other mechanical stresses on wound repair are needed.

Inhaled stimuli, such as $\mathrm{H}_{2} \mathrm{O}_{2}$ [106] and cigarette smoke [107], have been reported to inhibit wound healing in airway epithelium. Based on the knowledge that inhaled particulate invaders can inflict damage to the epithelium of the host and that the epithelium is capable of mounting a coordinated innate immune defence, KOFF et al. [108] hypothesised that the host epithelium intercepts the invader's signalling and responds by mounting responses that destroy the invader and repair associated epithelial damage. Gram-negative bacteria are important in the pathophysiology of airway diseases, including CF [109], bronchiectasis [110] and COPD exacerbations [111]. P. aeruginosa and its virulence factors damage the airway epithelium. KoFf et al. [108] showed that nontoxic levels of $P$. aeruginosa LPS accelerate wound repair via a complex signalling pathway that includes TLR4, PKC, Duox1, ROS, TACE, TGF- $\alpha$ and EGFR phosphorylation. However, at concentrations that were toxic to the epithelial cells, LPS inhibited wound repair. The response to low concentrations of the LPS stimulus suggests that airway epithelium provides an important function by activating host defences. Higher concentrations of LPS overcame this repair response. This cytotoxicity could initiate epithelial damage and facilitate invasion. Cigarette smoke extract is also reported to inhibit repair responses in human airway epithelial cells [107]. High concentrations of cigarette smoke extract were toxic to airway epithelial cells, whereas low concentrations enhanced cell survival [92]. Nicotine, a product contained in cigarette smoke, activates epithelial cell migration and wound repair via activation of the GPCR $\alpha 3 \alpha 5 \beta 2$-nicotinic acetylcholine receptors [78]. It is suggested that nicotine at low concentrations promotes acetylcholine receptor-mediated EGFR activation that may result in cell migration, whereas higher concentrations of nicotine are toxic to the cells. Thus, the concentrations of the various molecules involved in surface signalling can determine the outcome, at least in part.

The epithelium may also cooperate with recruited cells in wound repair. Thus, macrophages isolated from wounds produce TGF- $\alpha$ [39]. Since EGFR ligands have been shown to stimulate wound repair, one of the roles that macrophages may play in the repair process is to provide EGFR ligands that can activate EGFR in the epithelium.

\section{EGFR AND EGFR LIGAND EXPRESSION IN HUMAN AIRWAYS}

In the airway epithelium of healthy subjects, EGFR expression is weak or absent $[98,112-114]$, but it is increased in the airway epithelium of asthmatics [98, 113, 114], smokers with normal lung function [11], patients with COPD [11, 115] and CF patients [116, 117]. This suggests that EGFR activation may play more obvious roles in inflammatory states than in healthy individuals.

In humans, the airway epithelium expresses EGFR ligands constitutively, including EGF, TGF- $\alpha$, HB-EGF, amphiregulin, heregulin and betacellulin $[10,115]$. Expression of several EGFR ligands has also been investigated in disease (e.g. asthma, COPD and CF) $[112,115-120]$. These studies either assessed only the expression of an individual EGFR ligand or relied on the specificity of antibodies to examine the expression of multiple EGFR ligands, which are structurally related and may crossreact with antibodies. The studies showed that EGFR ligands are expressed in normal and diseased epithelia, but their expression pattern and distribution are variable. The respective roles of individual EGFR ligands in eliciting various EGFR-dependent physiological responses are largely unknown. It is suggested that activation of EGFR by different ligands results in changes in the activation of different intracellular pathways, which causes 
different responses [121]. Since cleavage of epithelial EGFR proligands leading to autocrine EGFR signalling appears to mediate the response to multiple noxious stimuli, it will be important to examine the roles of individual EGFR ligands in these responses to different stimuli.

\section{INNATE IMMUNE RESPONSES IN HEALTH AND DISEASE}

\section{Airway mucus}

Normal mucus

Normally, the mucociliary escalator provides a potent protective response to inhaled invaders. On the epithelial surface of conducting airways is a periciliary sol phase consisting of liquid that allows cilia to move, propelling the mucous gel floating above the cilia towards the mouth. In large conducting airways, coughing shears secreted materials and assists in their clearance. Mucus is a complex mixture of lipids and proteins, together with a liquid phase composed of water and electrolytes. Secreted gel-forming mucins are high molecular weight mucous glycoproteins that contribute to the formation of the mucous gel. Among these key constituents of mucus, MUC5AC and MUC5B mucins have been found most convincingly in human airway mucus $[12,122-124]$. Mucins are normally produced by cells in the mucous tubules of submucosal glands and by goblet cells in the airway surface epithelium. In healthy individuals, submucosal glands are small [119] and the airway surface epithelium contains few goblet cells [113, 117, 124]. The secreted thin mucous gel spreads on the epithelial surface. Inhaled invaders (e.g. bacteria and other particulates) are trapped in this mucous gel and are removed from the airway via mucociliary clearance and coughing $[7,8]$. These clearance mechanisms defend the host from attack by microbes and other inhaled irritants that deposit in the airways.

\section{Mucous hypersecretion}

In many respiratory diseases (e.g. asthma, COPD and CF), pathological studies report an increase in submucosal gland size in large airways $[119,125,126]$ and/or an increase in epithelial goblet cells in both large [125, 127, 128] and small airways [117, 125, 129]. This increase in mucin-producing cells is associated with increased mucin expression [11, 117, 119, $124,127,130,131]$. Anatomical considerations predict that the consequences of mucin hypersecretion should be different in large versus small airways.

Mucins in large conducting airways are produced by both airway epithelium [11, 127] and submucosal glands [132]. Mucins secreted by glands are transported into gland ducts, which terminate in the airway lumen. Gland ducts are concentrated at airway bifurcations, which are also the sites of cough receptors [8]. This localisation facilitates cough clearance of mucus secreted by glands. Secretion of mucins by proximal airway glands is predicted to result in cough and sputum production, the main symptoms of chronic bronchitis.

Small (peripheral) airways do not contain glands, and mucins in these airways are produced only by surface epithelial cells. Mucous hypersecretion in peripheral airways may result in airway plugging (mucous obstruction). Local overproduction of mucins by the surface epithelium is presumed to produce peripheral plugging. However, retrograde movement of mucins produced in large airways by aspiration is another, possibly major, cause of plugging.

Several anatomical features make the peripheral airways more likely to become obstructed by accumulated mucus than the large conducting airways, for the following reasons. First, when mucin-containing cells degranulate, the mucin volume can increase $>1,000$-fold due to hydration [133]. Thus, degranulated goblet cell mucins are more likely to obstruct airways of small diameter. Secondly, epithelial cells of patients with goblet cell hyperplasia have a larger volume and, therefore, occupy a larger percentage of the airway lumen than the epithelium of healthy control subjects, exaggerating the effects of mucous secretion. Thirdly, associated contraction of airway smooth muscle in the affected airway narrows the airway lumen further, again exaggerating the effects of mucous secretion (fig. 2).

Since small airways in normal lungs make only a small contribution to total airway resistance [135], abnormalities in these airways cause few clinical manifestations until most of the peripheral airways are occluded. However, extensive obstruction of small airways may result in significant airflow limitation in chronic airway inflammatory disease. It is predicted that plugging of $75 \%$ of all small airways is required before changes can be detected by routine pulmonary function tests (e.g. forced expiratory volume in one second) [136]. The relative absence of clinical manifestations, the limitations of physiological measures of small airway function in COPD and the difficulties of sampling these airways in human subjects are responsible for the limited recognition of the important pathophysiological roles of mucous plugging in small airways. In subjects with COPD, HoGG et al. [137] studied surgically removed tissues and found that the extent of small airway plugging increased in association with increasing airflow limitation, suggesting that mucous plugging is associated with the progression of COPD. In a subsequent study, HoGG et al. [138] showed that the extent of mucous plugging in peripheral airways predicts 3-yr mortality in subjects with severe COPD. SAETTA et al. [129] described goblet cell hyperplasia in peripheral airways of COPD subjects with chronic bronchitis. This hypertrophic epithelium increased the volume of tissue in the wall of small airways, another important determinant of airflow limitation in COPD [137]. Thus, it is suggested that both goblet cell hyperplasia and small airway plugging contribute to airflow limitation in COPD. These structural abnormalities are also found in subjects with advanced $\mathrm{CF}$, contributing to the clinical deterioration of respiratory function in this condition [117].

Mucous plugging in small airways has long been known to occur in acute fatal asthma [130, 134, 139]. KUYPER et al. [140] studied airways in 93 patients who died with acute asthma and concluded that extensive mucous plugging was a major feature in most, if not all, patients dying of asthma. It is likely that mucous plugging in peripheral airways contributed to death, presumably by reducing ventilation and gas exchange. Whether plugging in small airways also occurs in chronic asthma and contributes to the development of poorly reversible airflow obstruction in severe asthmatics is unknown, because peripheral airway tissue from asthmatics is not widely available. 
a)

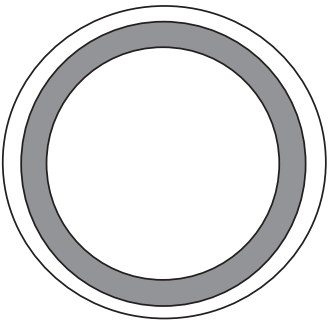

c)

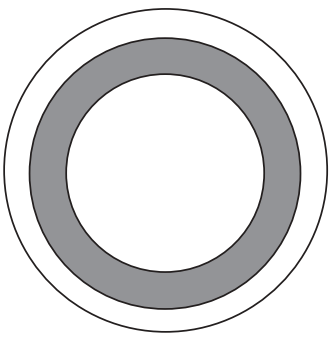

e)

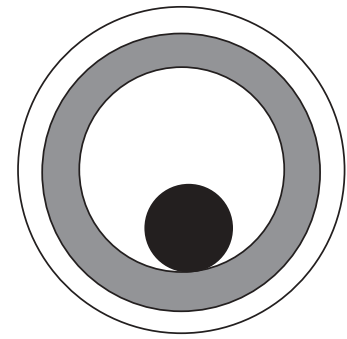

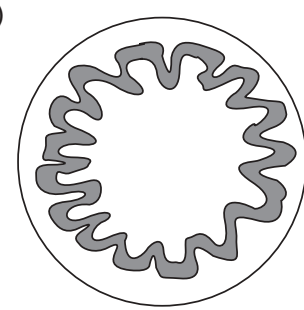

d)

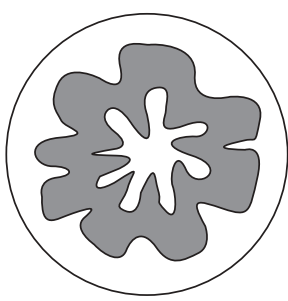

f)

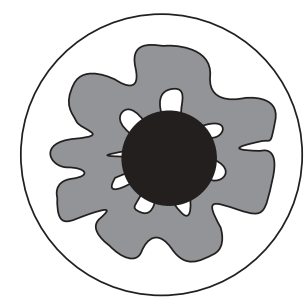

FIGURE 2. Schematic representation of the potential impact of goblet cell hyperplasia and mucous plugging on small airway obstruction. In normal individuals, the surface epithelium covering small airways contains few goblet cells and is composed of a thin layer of epithelial cells. Normal, thin epithelium ( $a$ and b) contributes little to luminal narrowing both when airway smooth muscle is relaxed (a) and when smooth muscle shortening occurs (b). In various airway inflammatory diseases (e.g. acute asthma, chronic obstructive pulmonary disease and cystic fibrosis), epithelial cell hyperplasia is present in small airway epithelium, resulting in epithelial thickening (c and d). When airway smooth muscle is relaxed (c), thickened epithelium contributes little to airflow limitation. However, because the thickness of the airway wall (composed of epithelium, lamina propria, muscle and adventitial compartments) is an important determinant of airflow limitation, when smooth muscle shortening occurs (d), hyperplastic epithelium is predicted to contribute to airflow obstruction [134]. When hyperplastic goblet cells release mucins in the airway lumen, swelling of secreted mucins during hydration may result in mucous obstruction (e and f). The contribution of mucous secretions to airflow limitation is likely to be increased when smooth muscle shortening occurs (f). Thus, both goblet cell hyperplasia and mucous obstruction in small airways are predicted to contribute significantly to the airflow limitation that occurs in chronic inflammatory airway diseases.

Another intriguing question is the relationship between bacterial colonisation of the airways and plugging in small airways. Normal airways are sterile [141]. However, in diseases associated with chronic small airway plugging (e.g. COPD and $\mathrm{CF})$, bacterial colonisation is a frequent finding [109, 141]. Bacteria (e.g. P. aeruginosa and Haemophilus influenzae) are known to adhere to mucins [5, 6, 142]. The adhesion of bacteria to mucins may result in bacterial phenotypic modification, e.g. production of alginate in a hypoxic environment within the mucous plugs [142], which contributes to the persistence of bacteria in the airways.

Relationship of EGFR expression to mucous hypersecretion Since multiple stimuli induce mucin production via EGFR activation in cultured airway epithelial cells and in the airways in animals, studies have been performed to determine EGFR and mucin expression in human airway tissues. Associations have been found between EGFR and mucin expression. TAKEYAMA et al. [113] studied bronchial biopsies obtained from healthy volunteers and subjects with mild-to-moderate asthma and found a positive correlation between EGFR immunoreactivity and MUC5AC mucin staining in the epithelium of healthy and asthmatic subjects, suggesting a causal relationship. O'DONNELL et al. [11] also studied expression of several members of the EGFR family of receptors in relation to mucin expression, comparing nonsmokers with current smokers with or without COPD. They concluded that long-term cigarette smoking is associated with enhanced expression of EGFR and mucin MUC5AC in the epithelium of proximal airways. Additionally, BURGEL et al. [117] found a positive correlation between mucin and EGFR staining in the small airway epithelium of subjects with advanced CF. Although these studies are compatible with the hypothesis that EGFR activation is responsible for increased mucin production in airway diseases, proof for this concept requires clinical studies using selective drugs that inhibit the EGFR cascade in individuals with chronic respiratory diseases associated with mucous hypersecretion.

\section{Neutrophil recruitment}

Recruitment of neutrophils to airways in disease

Chronic airway diseases (e.g. CF and COPD) have long been known to be associated with neutrophil infiltration into the airways [143, 144], and acute [145, 146] and chronic severe asthma [147] have been added to this list. IL-8 is believed to be one of the major neutrophil chemoattractants in airway diseases and is a target for the treatment of neutrophilic airway diseases [148]. For example, sputum from patients with CF was found to contain high levels of IL-8, and an antibody to IL-8 inhibited neutrophil chemotactic activity in the sputum of patients with CF [86]. Neutrophilic inflammation is a common and important manifestation of chronic airway diseases, so it is surprising that effective therapeutic intervention has not been accomplished.

\section{Relationship between EGFR and IL-8 expression and neutrophil recruitment}

In CF airway tissues removed at transplantation, IL-8 staining was increased in the epithelium and was co-localised with mucins [117]. Furthermore, IL-8 and mucin expression were positively correlated with EGFR expression in the airway epithelium, and neutrophils were increased in the epithelium and in the lumen of CF airways [117]. HAMILTON et al. [149] also found a strong correlation between IL-8 and EGFR expression in the epithelium of subjects with severe asthma. Animal studies have definitively indicated that both IL-8 and mucin production in airway epithelial cells involve EGFR activation. However, determination of the importance of these findings in human diseases will require clinical studies using EGFR inhibitors.

Interactions between neutrophils and mucins

In response to noxious stimuli (e.g. bacteria), airway epithelial cells produce both mucins and IL-8, suggesting that neutrophils 
and mucins could cooperate in the defence of the host. Thus, neutrophils and their products have been implicated in the production of mucins by epithelial cells, in the secretion of mucins in the airways and in the degradation of the secreted mucins.

Neutrophil products induce mucin gene and protein synthesis in airway epithelial cells [28]. Thus, both neutrophil-derived ROS [150] and neutrophil elastase [47, 60] have been shown to induce mucin gene and protein synthesis in airway epithelial cells via EGFR-dependent mechanisms.

Experimental studies indicate that when neutrophils are recruited to the airways, their close contact with airway epithelial goblet cells triggers mucin secretion from epithelial cells [151, 152]. This effect of recruited neutrophils on mucin secretion is mediated by neutrophil elastase proteolytic activity [152]. Thus, neutrophil proteases (e.g. elastase, cathepsin G and proteinase 3) are potent secretagogues for airway and submucosal gland epithelial cells [153, 154]. In CF tissues, BURGEL et al. [117] found that mucin secretions were increased in the lumens of small airways. The presence of mucins varied among different areas of epithelium, and neutrophil numbers in epithelium were inversely correlated with mucin contents in epithelium, suggesting that recruited neutrophils trigger mucin secretion [117]. Representative photomicrographs are shown in figure 3.

Neutrophil proteases also induce the proteolytic degradation of mucins in vitro $[28,155,156]$ and in vivo $[155,156]$. DAVIES et al. [157] suggested that neutrophil proteases present in $\mathrm{CF}$ sputum cleave MUC5AC and MUC5B mucins into small fragments that do not react with the usual antibodies. They also suggested that MUC5AC mucin is more susceptible to proteolytic degradation than MUC5B [157]. The roles of neutrophil-dependent mucin degradation in the clearance of mucous secretions and in the pathogenesis of airway mucous obstruction deserve future studies.

The complex interactions between neutrophils and mucins have important implications for studies of mucins in clinical diseases. HAYS and FAHY [119] found only a modest increase in mucin content in airway epithelium obtained from bronchial biopsies of CF subjects compared with the epithelium of healthy volunteers. They suggested that the relatively low amounts of mucins in goblet cells in CF epithelium could be related to ongoing degranulation signals (via recruited neutrophils) [119]. Since ongoing mucin secretion decreases mucin content in epithelium that actively produces and secretes mucins, the current authors suggest that in diseases associated with marked neutrophilic infiltration (e.g. CF and exacerbations of COPD), investigators should, when possible, examine both gene and protein expression of mucin.

\section{Epithelial damage in airway diseases}

Evidence for epithelial damage in airway diseases

Experimental airway epithelial damage in humans has proven difficult to examine because wounding causes significant sideeffects (e.g. bleeding). Furthermore, sampling of the airway epithelium in humans often involves bronchial biopsy, which can itself mechanically damage the epithelium, making the assessment of epithelial damage subject to bias [158].

Inhaled bacteria that deposit on the airway epithelial surface can damage the protective barrier of the airway epithelium [159]. Inhaled allergens and other irritants may also induce epithelial damage. In experiments with guinea pigs, allergic sensitisation with ovalbumin caused localised areas of tracheal epithelial damage associated with an intense, rapid restitution process [160]. In atopic humans sensitised to house dust mite, inhalation of this allergen was associated with proliferation of the airway epithelium [161]. Obvious epithelial damage was not identified in biopsies sampled $48 \mathrm{~h}$ after the challenge [161].

LAITINEN et al. [162] studied bronchial biopsies and reported epithelial cell disruption in asthmatic airways. MARGUET et al. [163] reported increased numbers of epithelial cells in the bronchoalveolar lavage fluid of asthmatic children and suggested that epithelial shedding occurred. Autopsy studies of subjects dying of status asthmaticus also showed extensive epithelial shedding [139], suggesting that airway epithelial damage is a significant aspect of the pathophysiology of asthma [164].
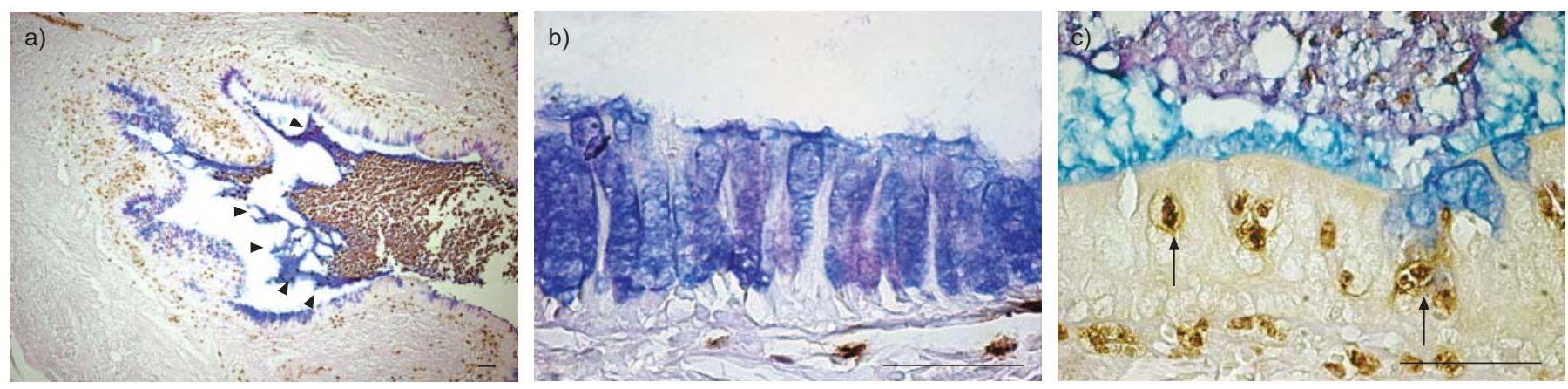

FIGURE 3. Representative photomicrographs of the relationship between mucins and neutrophils in airway sections from a patient undergoing lung transplantation for cystic fibrosis. Sections were stained with a monoclonal antibody to human neutrophil elastase (brown) and counterstained with Alcian blue/Periodic acid-Schiff (AB/PAS) for mucous glycoconjugates. a) Large numbers of neutrophils were seen within the airway lumen and AB/PAS in the lumen was localised to the periphery of the plug (arrowheads). b) In the epithelium where large amounts of mucous glycoconjugates were present, no neutrophils were found in the epithelium. c) In areas where large numbers of neutrophils were found in the epithelium (arrows), only small amounts of mucous glycoconjugates were present within the epithelium, but large amounts of mucous glycoconjugates were present in the lumen adjacent to the epithelial cells, suggesting goblet cell degranulation. Reproduced from [117] with permission from the publisher. Scale bars $=50 \mu \mathrm{m}$. 
In asthma, the current authors conclude that, although the methods of sampling can create artefacts in epithelial tissue, there is considerable data implicating epithelial damage. Future studies of mechanisms underlying the causes of this epithelial damage may provide new avenues for improving asthma treatment.

\section{Relationship of EGFR expression to epithelial damage}

PudDicombe et al. [98] studied the expression of EGFR in airway epithelium in relation to epithelial disruption in asthma. They reported that areas of epithelial damage exhibited a strong EGFR immunoreactivity and suggested that EGFR activation plays an important role in the epithelial damage/repair process in asthma [98]. However, it is unlikely that epithelial damage is the only reason for increased EGFR expression in asthmatic epithelium, since EGFR staining was also increased in morphologically intact epithelium [98]. Other stimuli, such as tumour necrosis factor- $\alpha$ secretion, which is increased in asthmatic airways [165] and induces EGFR expression in airway epithelium [32], could explain the increase in EGFR expression.

\section{SUMMARY, IMPLICATIONS FOR THERAPY, AND FUTURE PERSPECTIVES}

The airway epithelium is the first site of contact with inhaled and potentially damaging particulates. In healthy individuals, low concentrations of inhaled invaders are cleared via immune mechanisms, usually without symptoms or obvious pathological findings. Inhaled microbes and foreign particulates depositing on the airway epithelial surface activate epithelial receptors, which transmit signals via various pathways including EGFR signalling. EGFR activation results in the production of molecules such as mucins (which assist in the clearance of foreign particulates) and IL-8 (which potently recruits neutrophils), and also stimulates epithelial repair [98, 108]. However, high concentrations of the pathogens, often in combination with specific abnormalities in the host, may induce or exaggerate disease. Thus, mucous hypersecretion and exaggerated neutrophil recruitment are thought to play important roles in the pathogenesis of chronic airway diseases. Current therapies have only limited effects on mucin production and secretion [166] and on neutrophil recruitment [143, 144]. Therapies inhibiting various aspects of the EGFR signalling cascade could be beneficial in individuals with excessive mucous, neutrophilic and other EGFR-mediated responses. In considering potential therapies, it will be important to weigh potential therapeutic benefits with possible side-effects.

Much remains to be learned concerning this signalling cascade, especially concerning selective signalling that determines specific outcomes. It is predicted that a careful temporal analysis of the signalling molecules involved in this immune signalling and the effects of different modes of stimulation and signalling (e.g. roles of different EGFR ligands and phosphorylation sites) will provide new insights. Future studies are also needed in order to evaluate the use of therapeutic modalities involving the cascades described in the present review.

Modulation of airway epithelial cell activity and responses to external and internal stimuli is complex, involving many molecules and multiple pathways. One aim of the present review is to encourage future investigations of the interactions of the epidermal growth factor receptor signalling pathways with other important epithelial signalling pathways.

\section{REFERENCES}

1 Martin TR, Frevert CW. Innate immunity in the lungs. Proc Am Thorac Soc 2005; 2: 403-411.

2 Zaas AK, Schwartz DA. Innate immunity and the lung: defense at the interface between host and environment. Trends Cardiovasc Med 2005; 15: 195-202.

3 Bals R, Hiemstra PS. Innate immunity in the lung: how epithelial cells fight against respiratory pathogens. Eur Respir J 2004; 23: 327-333.

4 Rogan MP, Geraghty P, Greene CM, O'Neill SJ, Taggart CC, McElvaney NG. Antimicrobial proteins and polypeptides in pulmonary innate defence. Respir Res 2006; 7: 29.

5 Davies J, Carlstedt I, Nilsson AK, et al. Binding of Haemophilus influenzae to purified mucins from the human respiratory tract. Infect Immun 1995; 63: 2485-2492.

6 Scharfman A, Van Brussel E, Houdret N, Lamblin G, Roussel P. Interactions between glycoconjugates from human respiratory airways and Pseudomonas aeruginosa. Am J Respir Crit Care Med 1996; 154: S163-S169.

7 Knowles MR, Boucher RC. Mucus clearance as a primary innate defense mechanism for mammalian airways. J Clin Invest 2002; 109: 571-577.

8 Widdicombe JG. Neurophysiology of the cough reflex. Eur Respir J 1995; 8: 1193-1202.

9 Holbro T, Hynes NE. ErbB receptors: directing key signaling networks throughout life. Annu Rev Pharmacol Toxicol 2004; 44: 195-217.

10 Polosa R, Prosperini G, Leir SH, Holgate ST, Lackie PM, Davies DE. Expression of c-erbB receptors and ligands in human bronchial mucosa. Am J Respir Cell Mol Biol 1999; 20: 914-923.

11 O'Donnell RA, Richter A, Ward J, et al. Expression of ErbB receptors and mucins in the airways of long term current smokers. Thorax 2004; 59: 1032-1040.

12 Rose MC, Voynow JA. Respiratory tract mucin genes and mucin glycoproteins in health and disease. Physiol Rev 2006; 86: 245-278.

13 Meezaman D, Charles P, Daskal E, Polymeropoulos MH, Martin BM, Rose MC. Cloning and analysis of cDNA encoding a major airway glycoprotein, human tracheobronchial mucin (MUC5). I Biol Chem 1994; 269: 12932-12939.

14 Gum JR Jr, Hicks JW, Toribara NW, Siddiki B, Kim YS. Molecular cloning of human intestinal mucin (MUC2) cDNA. Identification of the amino terminus and overall sequence similarity to prepro-von Willebrand factor. J Biol Chem 1994; 269: 2440-2446.

15 Desseyn JL, Aubert JP, Van Seuningen I, Porchet N, Laine A. Genomic organization of the $3^{\prime}$ region of the human mucin gene MUC5B. J Biol Chem 1997; 272: 16873-16883.

16 Li D, Gallup M, Fan N, Szymkowski DE, Basbaum CB. Cloning of the amino-terminal and 5'-flanking region of the human MUC5AC mucin gene and transcriptional 
up-regulation by bacterial exoproducts. J Biol Chem 1998; 273: 6812-6820.

17 Guzman K, Gray TE, Yoon JH, Nettesheim P. Quantitation of mucin RNA by PCR reveals induction of both MUC2 and MUC5AC mRNA levels by retinoids. Am J Physiol 1996; 271: L1023-L1028.

18 Jany B, Gallup M, Tsuda T, Basbaum C. Mucin gene expression in rat airways following infection and irritation. Biochem Biophys Res Commun 1991; 181: 1-8.

19 Levine SJ, Larivée P, Logun C, Angus CW, Ognibene FP, Shelhamer JH. Tumor necrosis factor- $\alpha$ induces mucin hypersecretion and MUC-2 gene expression by human airway epithelial cells. Am J Respir Cell Mol Biol 1995; 12: 196-204.

20 Lou YP, Takeyama K, Grattan KM, et al. Plateletactivating factor induces goblet cell hyperplasia and mucin gene expression in airways. Am J Respir Crit Care Med 1998; 157: 1927-1934.

21 Harkema JR, Hotchkiss JA. Ozone- and endotoxininduced mucous cell metaplasias in rat airway epithelium: novel animal models to study toxicant-induced epithelial transformation in airways. Toxicol Lett 1993; 68 : 251-263.

22 Borchers MT, Wert SE, Leikauf GD. Acrolein-induced MUC5AC expression in rat airways. Am J Physiol 1998; 274: L573-L581.

23 Longphre M, Li D, Gallup M, et al. Allergen-induced IL-9 directly stimulates mucin transcription in respiratory epithelial cells. J Clin Invest 1999; 104: 1375-1382.

24 Zuhdi Alimam M, Piazza FM, Selby DM, Letwin N, Huang L, Rose MC. Muc-5/5ac mucin messenger RNA and protein expression is a marker of goblet cell metaplasia in murine airways. Am J Respir Cell Mol Biol 2000; 22: 253-260.

25 Temann UA, Prasad B, Gallup MW, et al. A novel role for murine IL-4 in vivo: induction of MUC5AC gene expression and mucin hypersecretion. Am J Respir Cell Mol Biol 1997; 16: 471-478.

26 Kondo M, Tamaoki J, Takeyama K, Nakata J, Nagai A. Interleukin-13 induces goblet cell differentiation in primary cell culture from guinea pig tracheal epithelium. Am J Respir Cell Mol Biol 2002; 27: 536-541.

27 Dabbagh K, Takeyama K, Lee HM, Ueki IF, Lausier JA, Nadel JA. IL-4 induces mucin gene expression and goblet cell metaplasia in vitro and in vivo. J Immunol 1999; 162: 6233-6237.

28 Voynow JA, Young LR, Wang Y, Horger T, Rose MC, Fischer BM. Neutrophil elastase increases MUC5AC mRNA and protein expression in respiratory epithelial cells. Am J Physiol Lung Cell Mol Physiol 1999; 276: L835-L843.

29 Dohrman A, Miyata S, Gallup M, et al. Mucin gene (MUC 2 and MUC 5AC) upregulation by Gram-positive and Gram-negative bacteria. Biochim Biophys Acta 1998; 1406: 251-259.

$30 \mathrm{Li}$ JD, Dohrman AF, Gallup M, et al. Transcriptional activation of mucin by Pseudomonas aeruginosa lipopolysaccharide in the pathogenesis of cystic fibrosis lung disease. Proc Natl Acad Sci USA 1997; 94: 967-972.

31 Li JD, Feng W, Gallup M, et al. Activation of NF-кB via a Src-dependent Ras-MAPK-pp90rsk pathway is required for Pseudomonas aeruginosa-induced mucin overproduction in epithelial cells. Proc Natl Acad Sci USA 1998; 95: 5718-5723.

32 Takeyama K, Dabbagh K, Lee HM, et al. Epidermal growth factor system regulates mucin production in airways. Proc Natl Acad Sci USA 1999; 96: 3081-3086.

33 Shim JJ, Dabbagh K, Ueki IF, et al. IL-13 induces mucin production by stimulating epidermal growth factor receptors and by activating neutrophils. Am J Physiol Lung Cell Mol Physiol 2001; 280: L134-L140.

34 Burgel PR, Nadel JA. Roles of epidermal growth factor receptor activation in epithelial cell repair and mucin production in airway epithelium. Thorax 2004; 59: 992-996.

35 Citri A, Yarden Y. EGF-ERBB signalling: towards the systems level. Nat Rev Mol Cell Biol 2006; 7: 505-516.

36 Wong DT, Weller PF, Galli SJ, et al. Human eosinophils express transforming growth factor- $\alpha$. J Exp Med 1990; 172: 673-681.

37 Burgel PR, Lazarus SC, Tam DC, et al. Human eosinophils induce mucin production in airway epithelial cells via epidermal growth factor receptor activation. J Immunol 2001; 167: 5948-5954.

38 Calafat J, Janssen H, Ståhle-Bäckdahl M, Zuurbier AE, Knol EF, Egesten A. Human monocytes and neutrophils store transforming growth factor- $\alpha$ in a subpopulation of cytoplasmic granules. Blood 1997; 90: 1255-1266.

39 Rappolee DA, Mark D, Banda MJ, Werb Z. Wound macrophages express TGF- $\alpha$ and other growth factors in vivo: analysis by mRNA phenotyping. Science 1988; 241: 708-712.

40 Okumura S, Sagara H, Fukuda T, Saito H, Okayama Y. FceRI-mediated amphiregulin production by human mast cells increases mucin gene expression in epithelial cells. J Allergy Clin Immunol 2005; 115: 272-279.

41 Daub H, Weiss FU, Wallasch C, Ullrich A. Role of transactivation of the EGF receptor in signalling by Gprotein-coupled receptors. Nature 1996; 379: 557-560.

42 Venkatakrishnan G, Salgia R, Groopman JE. Chemokine receptors $\mathrm{CXCR}-1 / 2$ activate mitogen-activated protein kinase via the epidermal growth factor receptor in ovarian cancer cells. J Biol Chem 2000; 275: 6868-6875.

43 Massagué J, Pandiella A. Membrane-anchored growth factors. Annu Rev Biochem 1993; 62: 515-541.

44 Tsai W, Morielli AD, Peralta EG. The m1 muscarinic acetylcholine receptor transactivates the EGF receptor to modulate ion channel activity. EMBO J 1997; 16: 4597-4605.

45 Prenzel N, Zwick E, Daub H, et al. EGF receptor transactivation by G-protein-coupled receptors requires metalloproteinase cleavage of proHB-EGF. Nature 1999; 402: 884-888.

46 Kohri K, Ueki IF, Shim JJ, et al. Pseudomonas aeruginosa induces MUC5AC production via epidermal growth factor receptor. Eur Respir J 2002; 20: 1263-1270.

47 Kohri K, Ueki IF, Nadel JA. Neutrophil elastase induces mucin production by ligand-dependent epidermal growth factor receptor activation. Am J Physiol Lung Cell Mol Physiol 2002; 283: L531-L540.

48 Black RA, Rauch CT, Kozlosky CJ, et al. A metalloproteinase disintegrin that releases tumour-necrosis factor- $\alpha$ from cells. Nature 1997; 385: 729-733. 
49 Schlöndorff J, Blobel CP. Metalloprotease-disintegrins: modular proteins capable of promoting cell-cell interactions and triggering signals by protein-ectodomain shedding. J Cell Sci 1999; 112: 3603-3617.

50 Peschon JJ, Slack JL, Reddy P, et al. An essential role for ectodomain shedding in mammalian development. Science 1998; 282: 1281-1284.

51 Shao MX, Ueki IF, Nadel JA. Tumor necrosis factor- $\alpha$ converting enzyme mediates MUC5AC mucin expression in cultured human airway epithelial cells. Proc Natl Acad Sci USA 2003; 100: 11618-11623.

52 Ohtsu H, Dempsey PJ, Eguchi S. ADAMs as mediators of EGF receptor transactivation by $G$ protein-coupled receptors. Am J Physiol Cell Physiol 2006; 291: C1-C10.

53 Lemjabbar H, Basbaum C. Platelet-activating factor receptor and ADAM10 mediate responses to Staphylococcus aureus in epithelial cells. Nat Med 2002; 8: 41-46.

54 Kinnula VL, Adler KB, Ackley NJ, Crapo JD. Release of reactive oxygen species by guinea pig tracheal epithelial cells in vitro. Am J Physiol 1992; 262: L708-L712.

55 Arnold RS, Shi J, Murad E, et al. Hydrogen peroxide mediates the cell growth and transformation caused by the mitogenic oxidase Nox1. Proc Natl Acad Sci USA 2001; 98: 5550-5555.

56 Shao MX, Nakanaga T, Nadel JA. Cigarette smoke induces MUC5AC mucin overproduction via tumor necrosis factor- $\alpha$ converting enzyme in human airway epithelial (NCI-H292) cells. Am J Physiol Lung Cell Mol Physiol 2004; 287: L420-L427.

57 Babior BM. The respiratory burst oxidase. Curr Opin Hematol 1995; 2: 55-60.

58 Geiszt M, Witta J, Baffi J, Lekstrom K, Leto TL. Dual oxidases represent novel hydrogen peroxide sources supporting mucosal surface host defense. FASEB J 2003; 17: 1502-1504.

59 De Deken X, Wang D, Many MC, et al. Cloning of two human thyroid cDNAs encoding new members of the NADPH oxidase family. J Biol Chem 2000; 275: 23227-23233.

60 Shao MX, Nadel JA. Neutrophil elastase induces MUC5AC mucin production in human airway epithelial cells via a cascade involving protein kinase $C$, reactive oxygen species, and TNF- $\alpha$ converting enzyme. J Immunol 2005; 175: 4009-4016.

61 Shao MX, Nadel JA. Dual oxidase 1-dependent MUC5AC mucin expression in cultured human airway epithelial cells. Proc Natl Acad Sci USA 2005; 102: 767-772.

62 Dusser DJ, Djokic TD, Borson DB, Nadel JA. Cigarette smoke induces bronchoconstrictor hyperresponsiveness to substance $\mathrm{P}$ and inactivates airway neutral endopeptidase in the guinea pig. Possible role of free radicals. J Clin Invest 1989; 84: 900-906.

63 Rahman I, Biswas SK, Kode A. Oxidant and antioxidant balance in the airways and airway diseases. Eur J Pharmacol 2006; 533: 222-239.

64 Akira S, Uematsu S, Takeuchi O. Pathogen recognition and innate immunity. Cell 2006; 124: 783-801.

65 Muir A, Soong G, Sokol S, et al. Toll-like receptors in normal and cystic fibrosis airway epithelial cells. Am J Respir Cell Mol Biol 2004; 30: 777-783.
66 Greene CM, Carroll TP, Smith SG, et al. TLR-induced inflammation in cystic fibrosis and non-cystic fibrosis airway epithelial cells. J Immunol 2005; 174: 1638-1646.

67 Mercer RR, Russell ML, Roggli VL, Crapo JD. Cell number and distribution in human and rat airways. Am J Respir Cell Mol Biol 1994; 10: 613-624.

68 DiMango E, Ratner AJ, Bryan R, Tabibi S, Prince A. Activation of NF- $\kappa \mathrm{B}$ by adherent Pseudomonas aeruginosa in normal and cystic fibrosis respiratory epithelial cells. J Clin Invest 1998; 101: 2598-2605.

69 Soong G, Reddy B, Sokol S, Adamo R, Prince A. TLR2 is mobilized into an apical lipid raft receptor complex to signal infection in airway epithelial cells. J Clin Invest 2004; 113: 1482-1489.

70 Groskreutz DJ, Monick MM, Powers LS, Yarovinsky TO, Look DC, Hunninghake GW. Respiratory syncytial virus induces TLR3 protein and protein kinase R, leading to increased double-stranded RNA responsiveness in airway epithelial cells. J Immunol 2006; 176: 1733-1740.

71 Guillot L, Medjane S, Le-Barillec K, et al. Response of human pulmonary epithelial cells to lipopolysaccharide involves Toll-like receptor 4 (TLR4)-dependent signaling pathways: evidence for an intracellular compartmentalization of TLR4. J Biol Chem 2004; 279: 2712-2718.

72 Gon Y, Asai Y, Hashimoto S, et al. A20 inhibits toll-like receptor 2- and 4-mediated interleukin-8 synthesis in airway epithelial cells. Am J Respir Cell Mol Biol 2004; 31: 330-336.

73 Nakanaga T, Nadel JA, Ueki IF, Koff JL, Shao MX. Regulation of interleukin-8 via an airway epithelial signaling cascade. Am J Physiol Lung Cell Mol Physiol 2007; 292: L1289-L1296.

74 Laroux FS, Romero X, Wetzler L, Engel P, Terhorst C. MyD88 controls phagocyte NADPH oxidase function and killing of gram-negative bacteria. J Immunol 2005; 175: 5596-5600.

75 McNamara N, Basbaum C. Signaling networks controlling mucin production in response to Gram-positive and Gram-negative bacteria. Glycoconj J 2001; 18: 715-722.

76 Luttrell LM, Daaka Y, Lefkowitz RJ. Regulation of tyrosine kinase cascades by G-protein-coupled receptors. Curr Opin Cell Biol 1999; 11: 177-183.

77 Fillon S, Soulis K, Rajasekaran S, et al. Platelet-activating factor receptor and innate immunity: uptake of grampositive bacterial cell wall into host cells and cell-specific pathophysiology. J Immunol 2006; 177: 6182-6191.

78 Tournier JM, Maouche K, Coraux C, et al. $\alpha 3 \alpha 5 \beta 2-$ Nicotinic acetylcholine receptor contributes to the wound repair of the respiratory epithelium by modulating intracellular calcium in migrating cells. Am J Pathol 2006; 168: 55-68.

79 Gómez MI, Seaghdha MO, Prince AS. Staphylococcus aureus protein A activates TACE through EGFR-dependent signaling. EMBO J 2007; 26: 701-709.

80 Greve JM, Davis G, Meyer AM, et al. The major human rhinovirus receptor is ICAM-1. Cell 1989; 56: 839-847.

81 Subauste MC, Jacoby DB, Richards SM, Proud D. Infection of a human respiratory epithelial cell line with rhinovirus. Induction of cytokine release and modulation of susceptibility to infection by cytokine exposure. J Clin Invest 1995; 96: 549-557. 
82 Nadel JA. Protease actions on airway secretions. Relevance to cystic fibrosis. Ann N Y Acad Sci 1991; 624: 286-296.

83 Nakamura H, Yoshimura K, Jaffe HA, Crystal RG. Interleukin-8 gene expression in human bronchial epithelial cells. J Biol Chem 1991; 266: 19611-19617.

84 Baggiolini M, Walz A, Kunkel SL. Neutrophil-activating peptide-1/interleukin 8 , a novel cytokine that activates neutrophils. J Clin Invest 1989; 84: 1045-1049.

85 Jorens PG, Graf PD, Ueki IF, Olesch J, Nadel JA. Interleukin-8 induces neutrophil accumulation in the trachea of allergic dogs. Trans Assoc Am Physicians 1992; 105: 190-196.

86 Richman-Eisenstat JB, Jorens PG, Hebert CA, Ueki I, Nadel JA. Interleukin-8: an important chemoattractant in sputum of patients with chronic inflammatory airway diseases. Am J Physiol 1993; 264: L413-L418.

87 Inoue $\mathrm{H}$, Massion PP, Ueki IF, et al. Pseudomonas stimulates interleukin- 8 mRNA expression selectively in airway epithelium, in gland ducts, and in recruited neutrophils. Am J Respir Cell Mol Biol 1994; 11: 651-663.

88 Massion PP, Inoue H, Richman-Eisenstat J, et al. Novel Pseudomonas product stimulates interleukin-8 production in airway epithelial cells in vitro. J Clin Invest 1994; 93: 26-32.

89 Massion PP, Hébert CA, Leong S, et al. Staphylococcus aureus stimulates neutrophil recruitment by stimulating interleukin-8 production in dog trachea. Am J Physiol 1995; 268: L85-L94.

90 Kaneko T, Massion PP, Hara M, Nadel JA. Ragweed antigen causes interleukin-8 production in sensitized dog trachea. Am J Respir Crit Care Med 1996; 153: 136-140.

91 Subauste MC, Proud D. Effects of tumor necrosis factor- $\alpha$, epidermal growth factor and transforming growth factor- $\alpha$ on interleukin- 8 production by, and human rhinovirus replication in, bronchial epithelial cells. Int Immunopharmacol 2001; 1: 1229-1234.

92 Richter A, O'Donnell RA, Powell RM, et al. Autocrine ligands for the epidermal growth factor receptor mediate interleukin-8 release from bronchial epithelial cells in response to cigarette smoke. Am J Respir Cell Mol Biol 2002; 27: 85-90.

93 Takeyama K, Jung B, Shim JJ, et al. Activation of epidermal growth factor receptors is responsible for mucin synthesis induced by cigarette smoke. Am J Physiol Lung Cell Mol Physiol 2001; 280: L165-L172.

94 Kuwahara I, Lillehoj EP, Lu W, et al. Neutrophil elastase induces IL-8 gene transcription and protein release through $\mathrm{p} 38 / \mathrm{NF}-\kappa \mathrm{B}$ activation via EGFR transactivation in a lung epithelial cell line. Am J Physiol Lung Cell Mol Physiol 2006; 291: L407-L416.

95 Thompson JS, Saxena SK, Sharp JG. Effect of the duration of infusion of urogastrone on intestinal regeneration in rabbits. Cell Tissue Kinet 1989; 22: 303-309.

96 Zahm JM, Chevillard M, Puchelle E. Wound repair of human surface respiratory epithelium. Am J Respir Cell Mol Biol 1991; 5: 242-248.

97 Kheradmand F, Folkesson HG, Shum L, Derynk R, Pytela R, Matthay MA. Transforming growth factor- $\alpha$ enhances alveolar epithelial cell repair in a new in vitro model. Am J Physiol 1994; 267: L728-L738.
98 Puddicombe SM, Polosa R, Richter A, et al. Involvement of the epidermal growth factor receptor in epithelial repair in asthma. FASEB J 2000; 14: 1362-1374.

99 Schultz G, Rotatori DS, Clark W. EGF and TGF- $\alpha$ in wound healing and repair. J Cell Biochem 1991; 45: 346-352.

100 Frey MR, Golovin A, Polk DB. Epidermal growth factorstimulated intestinal epithelial cell migration requires Src family kinase-dependent p38 MAPK signaling. J Biol Chem 2004; 279: 44513-44521.

101 Matthay MA, Thiery JP, Lafont F, Stampfer F, Boyer B. Transient effect of epidermal growth factor on the motility of an immortalized mammary epithelial cell line. J Cell Sci 1993; 106: 869-878.

102 Schultz GS, White M, Mitchell R, et al. Epithelial wound healing enhanced by transforming growth factor- $\alpha$ and vaccinia growth factor. Science 1987; 235: 350-352.

103 Hebda PA. Stimulatory effects of transforming growth factor- $\beta$ and epidermal growth factor on epidermal cell outgrowth from porcine skin explant cultures. I Invest Dermatol 1988; 91: 440-445.

104 Schäfer R, Sedehizade F, Welte T, Reiser G. ATP- and UTP-activated P2Y receptors differently regulate proliferation of human lung epithelial tumor cells. Am J Physiol Lung Cell Mol Physiol 2003; 285: L376-L385.

105 Müller T, Bayer H, Myrtek D, et al. The P2Y14 receptor of airway epithelial cells: coupling to intracellular $\mathrm{Ca} 2+$ and IL-8 secretion. Am J Respir Cell Mol Biol 2005; 33: 601-609.

106 Geiser T, Ishigaki M, van Leer C, Matthay MA, Broaddus VC. $\mathrm{H}_{2} \mathrm{O}_{2}$ inhibits alveolar epithelial wound repair in vitro by induction of apoptosis. Am J Physiol Lung Cell Mol Physiol 2004; 287: L448-L453.

107 Wang $H$, Liu X, Umino T, et al. Cigarette smoke inhibits human bronchial epithelial cell repair processes. Am J Respir Cell Mol Biol 2001; 25: 772-779.

108 Koff JL, Shao MX, Kim S, Ueki IF, Nadel JA. Pseudomonas lipopolysaccharide accelerates wound repair via activation of a novel epithelial cell signaling cascade. J Immunol 2006; 177: 8693-8700.

109 Gibson RL, Burns JL, Ramsey BW. Pathophysiology and management of pulmonary infections in cystic fibrosis. Am J Respir Crit Care Med 2003; 168: 901-951.

110 Barker AF. Bronchiectasis. N Engl J Med 2002; 346: 1383-1393.

111 Sethi S, Evans N, Grant BJ, Murphy TF. New strains of bacteria and exacerbations of chronic obstructive pulmonary disease. N Engl J Med 2002; 347: 465-471.

112 Amishima M, Munakata M, Nasuhara Y, et al. Expression of epidermal growth factor and epidermal growth factor receptor immunoreactivity in the asthmatic human airway. Am J Respir Crit Care Med 1998; 157: 1907-1912.

113 Takeyama K, Fahy JV, Nadel JA. Relationship of epidermal growth factor receptors to airway goblet cell production. Am J Respir Crit Care Med 2001; 163: 511-516.

114 Polosa R, Puddicombe SM, Krishna MT, et al. Expression of c-erbB receptors and ligands in the bronchial epithelium of asthmatic subjects. J Allergy Clin Immunol 2002; 109: 75-81.

115 de Boer WI, Hau CM, van Schadewijk A, Stolk J, van Krieken JH, Hiemstra PS. Expression of epidermal growth factors and their receptors in the bronchial 
epithelium of subjects with chronic obstructive pulmonary disease. Am J Clin Pathol 2006; 125: 184-192.

116 Voynow JA, Fischer BM, Roberts BC, Proia AD. Basal-like cells constitute the proliferating cell population in cystic fibrosis airways. Am J Respir Crit Care Med 2005; 172: 1013-1018.

117 Burgel PR, Montani D, Danel C, Dusser DJ, Nadel JA. A morphometric study of mucins and small airway plugging in cystic fibrosis. Thorax 2007; 62: 153-161.

118 Hardie WD, Bejarano PA, Miller MA, et al. Immunolocalization of transforming growth factor- $\alpha$ and epidermal growth factor receptor in lungs of patients with cystic fibrosis. Pediatr Dev Pathol 1999; 2: 415-423.

119 Hays SR, Fahy JV. Characterizing mucous cell remodeling in cystic fibrosis: relationship to neutrophils. Am J Respir Crit Care Med 2006; 174: 1018-1024.

120 Fan YX, Wong L, Deb TB, Johnson GR. Ligand regulates epidermal growth factor receptor kinase specificity: activation increases preference for GAB1 and SHC versus autophosphorylation sites. J Biol Chem 2004; 279: 3814338150 .

121 Andrianifahanana M, Moniaux N, Batra SK. Regulation of mucin expression: mechanistic aspects and implications for cancer and inflammatory diseases. Biochim Biophys Acta 2006; 1765: 189-222.

122 Thornton DJ, Sheehan JK. From mucins to mucus. Toward a more coherent understanding of this essential barrier. Proc Am Thorac Soc 2004; 1: 54-61.

123 Williams OW, Sharafkhaneh A, Kim V, Dickey BF, Evans CM. Airway mucus: from production to secretion. Am J Respir Cell Mol Biol 2006; 34: 527-536.

124 Ordoñez CL, Khashayar R, Wong $\mathrm{HH}$, et al. Mild and moderate asthma is associated with airway goblet cell hyperplasia and abnormalities in mucin gene expression. Am J Respir Crit Care Med 2001; 163: 517-523.

125 Aikawa T, Shimura S, Sasaki H, Ebina M, Takishima T. Marked goblet cell hyperplasia with mucus accumulation in the airways of patients who died of severe acute asthma attack. Chest 1992; 101: 916-921.

126 Carroll NG, Cooke C, James AL. Bronchial blood vessel dimensions in asthma. Am J Respir Crit Care Med 1997; 155: 689-695.

127 Innes AL, Woodruff PG, Ferrando RE, et al. Epithelial mucin stores are increased in the large airways of smokers with airflow obstruction. Chest 2006; 130: 1102-1108.

128 Hauber HP, Tsicopoulos A, Wallaert B, et al. Expression of HCLCA1 in cystic fibrosis lungs is associated with mucus overproduction. Eur Respir J 2004; 23: 846-850.

129 Saetta M, Turato G, Baraldo S, et al. Goblet cell hyperplasia and epithelial inflammation in peripheral airways of smokers with both symptoms of chronic bronchitis and chronic airflow limitation. Am J Respir Crit Care Med 2000; 161: 1016-1021.

130 Groneberg DA, Eynott PR, Lim S, et al. Expression of respiratory mucins in fatal status asthmaticus and mild asthma. Histopathology 2002; 40: 367-373.

131 Caramori G, Di Gregorio C, Carlstedt I, et al. Mucin expression in peripheral airways of patients with chronic obstructive pulmonary disease. Histopathology 2004; 45: 477-484.
132 Hovenberg HW, Davies JR, Carlstedt I. Different mucins are produced by the surface epithelium and the submucosa in human trachea: identification of MUC5AC as a major mucin from the goblet cells. Biochem J 1996; 318: 319-324.

133 Verdugo P. Goblet cells secretion and mucogenesis. Annu Rev Physiol 1990; 52: 157-176.

134 Shimura S, Andoh Y, Haraguchi M, Shirato K. Continuity of airway goblet cells and intraluminal mucus in the airways of patients with bronchial asthma. Eur Respir J 1996; 9: 1395-1401.

135 Hogg JC. Pathophysiology of airflow limitation in chronic obstructive pulmonary disease. Lancet 2004; 364: 709-721.

136 Cosio M, Ghezzo H, Hogg JC, et al. The relations between structural changes in small airways and pulmonaryfunction tests. N Engl J Med 1978; 298: 1277-1281.

137 Hogg JC, Chu F, Utokaparch S, et al. The nature of smallairway obstruction in chronic obstructive pulmonary disease. N Engl J Med 2004; 350: 2645-2653.

138 Hogg JC, Chu FS, Tan WC, et al. Survival after lung volume reduction in chronic obstructive pulmonary disease: insights from small airway pathology. Am J Respir Crit Care Med 2007; 176: 454-459.

139 Dunnill MS. The pathology of asthma with special reference to changes in the bronchial mucosa. J Clin Pathol 1960; 13: 27-33.

140 Kuyper LM, Paré PD, Hogg JC, et al. Characterization of airway plugging in fatal asthma. Am J Med 2003; 115: 6-11.

141 Rosell A, Monsó E, Soler N, et al. Microbiologic determinants of exacerbation in chronic obstructive pulmonary disease. Arch Intern Med 2005; 165: 891-897.

142 Worlitzsch D, Tarran R, Ulrich M, et al. Effects of reduced mucus oxygen concentration in airway Pseudomonas infections of cystic fibrosis patients. J Clin Invest 2002; 109: 317-325.

143 Barnes PJ, Stockley RA. COPD: current therapeutic interventions and future approaches. Eur Respir J 2005; 25: 1084-1106.

144 Rowe SM, Miller S, Sorscher EJ. Cystic fibrosis. N Engl J Med 2005; 352: 1992-2001.

145 Lamblin C, Gosset P, Tillie-Leblond I, et al. Bronchial neutrophilia in patients with noninfectious status asthmaticus. Am J Respir Crit Care Med 1998; 157: 394-402.

146 Ordoñez CL, Shaughnessy TE, Matthay MA, Fahy JV. Increased neutrophil numbers and IL-8 levels in airway secretions in acute severe asthma: clinical and biologic significance. Am J Respir Crit Care Med 2000; 161: 1185-1190.

147 Wenzel SE, Szefler SJ, Leung DY, Sloan SI, Rex MD, Martin RJ. Bronchoscopic evaluation of severe asthma. Persistent inflammation associated with high dose glucocorticoids. Am J Respir Crit Care Med 1997; 156: 737-743.

148 Barnes PJ. New molecular targets for the treatment of neutrophilic diseases. J Allergy Clin Immunol 2007; 119: 1055-1062.

149 Hamilton LM, Torres-Lozano C, Puddicombe SM, et al. The role of the epidermal growth factor receptor in sustaining neutrophil inflammation in severe asthma. Clin Exp Allergy 2003; 33: 233-240.

150 Takeyama K, Dabbagh K, Jeong Shim J, Dao-Pick T, Ueki IF, Nadel JA. Oxidative stress causes mucin synthesis via transactivation of epidermal growth factor receptor: role of neutrophils. J Immunol 2000; 164: 1546-1552. 
151 Agusti C, Takeyama K, Cardell LO, et al. Goblet cell degranulation after antigen challenge in sensitized guinea pigs. Role of neutrophils. Am J Respir Crit Care Med 1998; 158: 1253-1258.

152 Takeyama K, Agusti C, Ueki I, Lausier J, Cardell LO, Nadel JA. Neutrophil-dependent goblet cell degranulation: role of membrane-bound elastase and adhesion molecules. Am J Physiol 1998; 275: L294-L302.

153 Sommerhoff CP, Nadel JA, Basbaum CB, Caughey GH. Neutrophil elastase and cathepsin G stimulate secretion from cultured bovine airway gland serous cells. J Clin Invest 1990; 85: 682-689.

154 Witko-Sarsat V, Halbwachs-Mecarelli L, Schuster A, et al. Proteinase 3, a potent secretagogue in airways, is present in cystic fibrosis sputum. Am J Respir Cell Mol Biol 1999; 20: 729-736.

155 Rose MC, Brown CF, Jacoby JZ 3rd, Lynn WS, Kaufman B. Biochemical properties of tracheobronchial mucins from cystic fibrosis and non-cystic fibrosis individuals. Pediatr Res 1987; 22: 545-551.

156 Gupta R, Jentoft N. The structure of tracheobronchial mucins from cystic fibrosis and control patients. J Biol Chem 1992; 267: 3160-3167.

157 Davies JR, Svitacheva N, Lannefors L, Kornfält R, Carlstedt I. Identification of MUC5B, MUC5AC and small amounts of MUC2 mucins in cystic fibrosis airway secretions. Biochem J 1999; 344: 321-330.

158 Ordoñez C, Ferrando R, Hyde DM, Wong HH, Fahy JV. Epithelial desquamation in asthma: artifact or pathology? Am J Respir Crit Care Med 2000; 162: 2324-2329.
159 Baltimore RS, Christie CD, Smith GJ. Immunohistopathologic localization of Pseudomonas aeruginosa in lungs from patients with cystic fibrosis. Implications for the pathogenesis of progressive lung deterioration. Am Rev Respir Dis 1989; 140: 1650-1661.

160 Erjefält JS, Korsgren M, Nilsson MC, Sundler F, Persson CG. Prompt epithelial damage and restitution processes in allergen challenged guinea-pig trachea in vivo. Clin Exp Allergy 1997; 27: 1458-1470.

161 Ricciardolo FL, Di Stefano A, van Krieken JH, et al. Proliferation and inflammation in bronchial epithelium after allergen in atopic asthmatics. Clin Exp Allergy 2003; 33: 905-911.

162 Laitinen LA, Heino M, Laitinen A, Kava T, Haahtela T. Damage of the airway epithelium and bronchial reactivity in patients with asthma. Am Rev Respir Dis 1985; 131: 599-606.

163 Marguet C, Jouen-Boedes F, Dean TP, Warner JO. Bronchoalveolar cell profiles in children with asthma, infantile wheeze, chronic cough, or cystic fibrosis. Am J Respir Crit Care Med 1999; 159: 1533-1540.

164 Boxall C, Holgate ST, Davies DE. The contribution of transforming growth factor- $\beta$ and epidermal growth factor signalling to airway remodelling in chronic asthma. Eur Respir J 2006; 27: 208-229.

165 Berry MA, Hargadon B, Shelley M, et al. Evidence of a role of tumor necrosis factor- $\alpha$ in refractory asthma. $N$ Engl J Med 2006; 354: 697-708.

166 Rogers DF, Barnes PJ. Treatment of airway mucus hypersecretion. Ann Med 2006; 38: 116-125. 